\title{
Targeting Angiotensin-Converting Enzyme-2/Angiotensin-(1-7)/ Mas Receptor Axis in the Vascular Progenitor Cells for Cardiovascular Diseases
}

\author{
Yagna P.R. Jarajapu \\ Department of Pharmaceutical Sciences, College of Health Professions, North Dakota State University, Fargo, North Dakota
}

Received June 18, 2019; accepted March 31, 2020

\begin{abstract}
Bone marrow-derived hematopoietic stem/progenitor cells are vasculogenic and play an important role in endothelial health and vascular homeostasis by participating in postnatal vasculogenesis. Progenitor cells are mobilized from bone marrow niches in response to remote ischemic injury and migrate to the areas of damage and stimulate revascularization largely by paracrine activation of angiogenic functions in the peri-ischemic vasculature. This innate vasoprotective mechanism is impaired in certain chronic clinical conditions, which leads to the development of cardiovascular complications. Members of the renin-angiotensin system-angiotensin-converting enzymes (ACEs) ACE and ACE2, angiotensin II (Ang II), Ang-(1-7), and receptors AT1 and Mas-are expressed in vasculogenic progenitor cells derived from humans and rodents. Ang-(1-7), generated by ACE2, is known to produce cardiovascular protective effects by acting on Mas receptor and is considered as a counter-regulatory mechanism to the detrimental effects of Ang II. Evidence has now been accumulating in support of the activation of the ACE2/ Ang-(1-7)/Mas receptor pathway by pharmacologic or molecular
\end{abstract}

maneuvers, which stimulates mobilization of progenitor cells from bone marrow, migration to areas of vascular damage, and revascularization of ischemic areas in pathologic conditions. This minireview summarizes recent studies that have enhanced our understanding of the physiology and pharmacology of vasoprotective axis in bone marrow-derived progenitor cells in health and disease.

\section{SIGNIFICANCE STATEMENT}

Hematopoietic stem progenitor cells (HSPCs) stimulate revascularization of ischemic areas. However, the reparative potential is diminished in certain chronic clinical conditions, leading to the development of cardiovascular diseases. ACE2 and Mas receptor are key members of the alternative axis of the renin-angiotensin system and are expressed in HSPCs. Accumulating evidence points to activation of ACE2 or Mas receptor as a promising approach for restoring the reparative potential, thereby preventing the development of ischemic vascular diseases.

\section{Introduction}

Discovery of the vasoreparative potential of hematopoietic stem progenitor cells (HSPCs) has introduced the novel concept of postnatal vascular development and exponentially increased our understanding of vascular regeneration (Asahara et al., 1997). This concept has rapidly transitioned into the clinical arena for determining their potential therapeutic benefit in cardiovascular diseases (Raval and Losordo, 2013). HSPCs with vasoreparative potential are frequently

This work is supported by an American Heart Association grant (17AIREA33700012) and National Institute of Aging of National Institutes of Health [AG056881] toY.P.R.J.

https://doi.org/10.1124/mol.119.117580. termed as endothelial progenitor cells or vascular progenitor cells by different research groups. These cells are primarily derived from bone marrow and are a subset of HSPCs that can directly participate in vascular re-endothelialization and regeneration, thus contributing to ischemic vascular repair and tissue regeneration primarily by restoring blood flow. Stimulating this innate vasoreparative mechanism by enhancing the mobilization of HSPCs from bone marrow into the circulation by pharmacologic or by cell-transplant approaches is a promising therapeutic strategy for the treatment of cardiovascular complications.

Discovery of angiotensin-converting enzyme-2 (ACE2) has led to the conception of the cardiovascular protective axis of the reninangiotensin system (RAS). ACE2 is a monocarboxypeptidase

ABBREVIATIONS: ACE, angiotensin-converting enzyme; ACEI, angiotensin-converting enzyme inhibitor; Ang, angiotensin; AT1R, angiotensin II receptor type 1; AT2R, angiotensin II receptor type 2; eNOS, endothelial nitric oxide synthase; EPC, endothelial progenitor cell; G-CSF, granulocyte colony stimulating factor; HIF, hypoxia-inducible factor-1 $\alpha$; HSC, hematopoietic stem cell; HSPC, hematopoietic stem progenitor cell; MasR, Mas receptor; NO, nitric oxide; RAS, renin-angiotensin system; SDF, stromal-derived factor-1 $\alpha$; VEGF, vascular endothelial growth factor; VEGFR2, vascular endothelial growth factor receptor type 2 . 
capable of cleaving Ang I to Ang-(1-9) or Ang II to Angiotensin(1-7) [Ang-(1-7)] (Donoghue et al., 2000; Tipnis et al., 2000; Vickers et al., 2002). In 2003, Mas receptor (MasR) was characterized as the cognate receptor mediating the cardiovascular protective functions of Ang-(1-7) (Santos et al., 2003). Thus, the ACE2/Ang-(1-7)/MasR axis constitutes the protective axis of RAS. This novel pathway has attracted massive attention and is being extensively studied for the development of novel therapeutic targets for cardiovascular, metabolic, and neurologic disorders. In recent years, several studies have shown evidence for an important role of the protective RAS in vascular progenitor cells. ACE2 and MasR are expressed in one or more subsets of bone marrow-derived HSPCs. Activation of the ACE2/Ang-(1-7)/MasR axis stimulates vascular repair-relevant functions of HSPCs in health and reverses dysfunction induced by chronic pathologic conditions. This minireview provides an overview of the discovery and clinical significance of vascular progenitor cells and then summarizes key reports that enhanced our understanding of the physiology and pharmacology of the ACE2/Ang-(1-7)/ MasR pathway in the progenitor cells and the implications for clinical applications.

\section{Discovery and Identity of Vascular Progenitor Cells}

Evidence for the existence of vascular progenitor cells dates back to 1963, when endothelialization of intravascular Dacron hub was postulated to be derived from circulating blood cells (Stump et al., 1963). This concept did not attract much attention until 1995, when definitive proof was provided (Wu et al., 1995). This study confirmed endothelial identity of cells by von Willebrand factor and Ulex europaeus agglutinin I staining on the flow surface of Dacron axillofemoral bypass graft, which was harvested after 26 months of implantation from a patient (Wu et al., 1995). In 1997, Asahara et al. (1997) reported successful isolation of putative vascular progenitor cells, termed as endothelial progenitor cells (EPCs), from human peripheral blood. Circulating CD34 ${ }^{+}$VEGFR2 ${ }^{+}$ mononuclear cells differentiated into endothelial-like cells when cultured on fibronectin, and the differentiated cells incorporated into the sites of active angiogenesis in animal models of ischemic injury. This study, indeed, provided evidence for postnatal vasculogenesis and triggered a massive interest among scientists worldwide about the true identity and clinical applications of progenitor cells for ischemic vascular complications.

Subsequent studies demonstrated EPC-like properties in cell populations identified by one or more of the following antigenic markers: CD34, CD133, CD45, VEGFR2, CXCR4 (C-X-C chemokine receptor type 4), CD14, CD31, or eNOS (Fernandez Pujol et al., 2000; Gehling et al., 2000; Peichev et al., 2000; Harraz et al., 2001; Quirici et al., 2001; Schmeisser et al., 2001; Awad et al., 2006; Loomans et al., 2006). Most of these phenotypes overlap with the known antigenic markers of HSPCs (Timmermans et al., 2009; Fadini et al., 2012; Yoder 2013). Although a true identity of a vascular progenitor cell in humans is still elusive, based on extensive clinical studies, CD34 antigen alone could represent a cell population of great clinical utility. CD34 is a sialomucin-like ligand for L-selectin and is commonly expressed on many hematopoietic progenitor cells that are either resident in bone marrow or in the circulation (Civin et al., 1984). The $\mathrm{CD}^{+} 4^{+}$cell population has been clinically used for reconstituting bone marrow cells after chemoradiation therapy (Demirer et al., 1999). Given the fact that the microvascular endothelial cells and tissues that support early vascular development express CD34 antigen (Tavian et al., 1996; Wood et al., 1997), CD34 ${ }^{+}$cells were believed to be EPCs that are capable of differentiating into vascular endothelium and stimulating vascularization (Asahara et al., 1997). Several clinical trials have employed a CD34 ${ }^{+}$HSPC population for determining the therapeutic potential of autologous cell therapies for cardiovascular complication (Quyyumi et al., 2017; Henry et al., 2018). (Please note that cord blood is an abundant source of several types of stem progenitor cells and possesses efficient vascular regenerative functions. Several other organs, including adipose tissue, are now known to have resident stem progenitor cells that are likely to have reparative functions. In this review, discussion is limited to adult CD34 ${ }^{+}$HSPCs that are derived from bone marrow.)

\section{From Bone Marrow to the Circulation: Mobilization of HSPCs}

Numerous experimental studies have provided evidence for bone marrow as a major source of circulating vascular progenitor cells, particularly the cells that home to areas requiring neovascularization or tissue healing after injury (Shi et al., 1998; Asahara et al., 1999). In dogs that underwent bone marrow transplantation with genetically distinct donor cells implanted with intravascular Dacron graft (Shi et al., 1998), endothelial cells that repopulated the graft were exclusively derived from bone marrow-resident donor cells. This was strongly supported by a subsequent study that used transgenic mice expressing $\beta$-galactosidase under transcriptional regulation of an endothelial cell-specific promoter (VEGFR2 or Tie2) as transplant donors (Asahara et al., 1999). $\beta$-galactosidase cells were incorporated in the areas of neovascularization after induction of myocardia or hindlimb ischemic injury or tumor development in the endometrium. These studies confirm that bone marrow-resident HSPCs are mobilized into the blood stream and contribute to physiologic or pathologic postnatal angiogenesis.

Bone marrow contains primitive HSCs, progenitor cells, non-HSCs, and blood cells that are derived from HSPCs. NonHSCs include osteoblasts, osteoclasts, endothelial cells, mesenchymal stromal cells, fibroblasts, adipocytes, nerve terminals, and mature blood cells. These cells form specialized niches either close to endosteum (osteoblastic niche) or vasculature (vascular niche). Quiescence, proliferation, or differentiation of HSCs is largely determined by the niche cells. In addition, they promote quiescence of HSCs by making direct contacts and via paracrine influences by secreting osteopontin or angiopoietin-1 (Mendez-Ferrer et al., 2010; Ding et al., 2012).

Quiescent and slowly dividing HSPCs preferentially reside in close interaction with osteoblasts and mesenchymal stromal cells (endosteal niche) (Kunisaki et al., 2013). On the other hand, rapidly proliferating cells reside around sinusoids and arterioles (Itkin et al., 2016). Under physiologic conditions, HSPCs actively enter the blood stream in a circadian pattern and eventually home back to bone marrow (Lucas et al., 2008; Casanova-Acebes et al., 2013). Although the function is to generate blood cell progenies in bone marrow, HSPCs are 
constantly found in circulation and appear to be responsible for tissue surveillance and to modulate homeostasis (Ballard and Edelberg 2007). HSPCs are mobilized in response to several circulating factors that are cues arising out of physiologic demands or pathologic changes. Ischemic vascular injury induces hypoxia-inducible factor- $1 \alpha$ (HIF), which in turn triggers expression of myriad factors into the circulation. $\mathrm{HIF}$ is rapidly stabilized in the environments of low oxygen tension and binds to its cognate hypoxia response elements within enhancer elements, HIF transcription factors, and increases the transcription of target genes (Wang et al., 1995). These downstream effectors of HIF teleologically aid in diverse biologic processes that aid in survival during hypoxia-for example, hematopoiesis or angiogenesis (Shweiki et al., 1992). HIF is stabilized by tumor hypoxic environment and induces angiogenesis, which is required to support rapid proliferation of cells (Maxwell et al., 1997). HIF stimulates recruitment and homing of bone marrow-derived HSPCs to areas of injury that were largely mediated by the expression of stromal-derived factor-1 $\alpha$ (SDF) (Sweeney et al., 2002; De Falco et al., 2004) and vascular endothelial growth factor (VEGF) (Forsythe et al., 1996; Takahashi et al., 1999; Gill et al., 2001), strong chemoattractant factors for vasoreparative HSPCs that are identified as major players in stimulating vascular growth and restoring blood flow to the areas of injury. Increasing the circulating levels of VEGF or SDF would mimic mobilization of HSPCs independent of HIF (Hattori et al., 2001; Burns et al., 2006) (Fig. 1). Other factors that are identified to stimulate mobilization of HSPCs from bone marrow include but are not limited to erythropoietin, thrombopoietin, granulocyte colony stimulating factor (G-CSF), and granulocyte-macrophage colony-stimulating factor (Jin et al., 2006; Grunewald et al., 2006), and this list is still increasing. G-CSF and plerixafor are clinically used mobilizers of bone marrow immune cells, and this response is always associated with mobilization of primitive progenitor cells, which stimulate vascular repair.

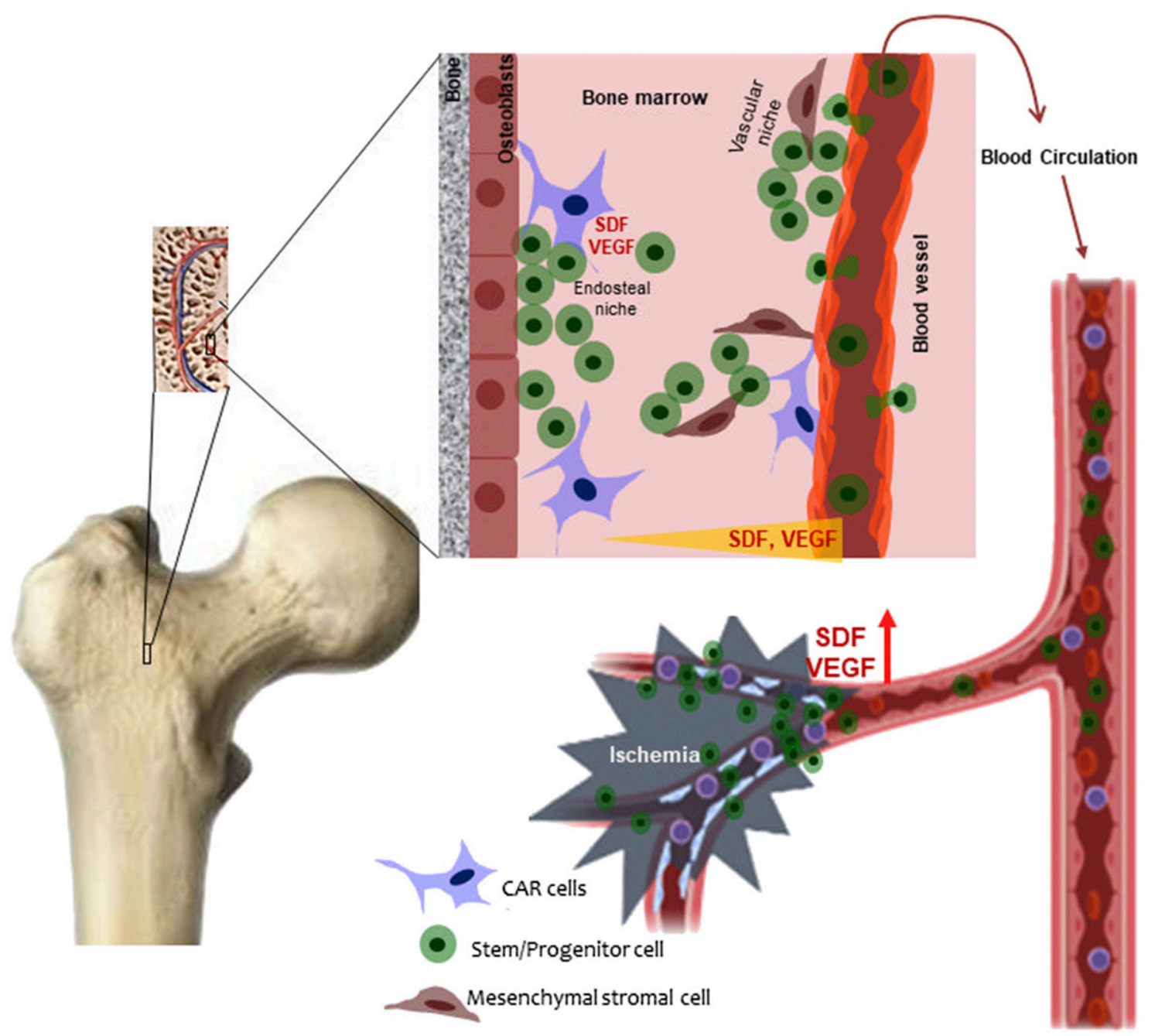

Fig. 1. Mobilization of hematopoietic progenitor cells (HSPCs) from bone marrow niches. HSPCs are known to reside in two distinct niches: endosteal and vascular niches. HSPCs in the vascular niche are rapidly proliferating and reside in close proximity to the sinusoids; therefore, they are readily available for mobilization into the blood stream in response to physiologic stimuli or pathologic demand. The bone marrow microenvironment contains several cell types, including osteoblasts, mesenchymal stromal cells, endothelial cells, CAR (CXCL12-abundant reticular) cells, fibroblasts, and adipocytes (not all are shown), many of which secrete SDF or vascular VEGF. These two factors indeed help to retain the cells in the bone marrow niches. A shift in the gradient of these factors relative to the concentration in the circulating blood dislodges cells from their niches and transmigrates the sinusoidal wall to peripheral blood. Ischemic tissues stimulate this process by generating SDF and VEGF, which rise to levels severalfold higher than that observed in bone marrow. Mobilized cells home to the areas of ischemia, extravasate into the ischemic tissues, and stimulate vascular regeneration either by trans-differentiation into endothelial cells or by releasing paracrine factors (see text for details). 
Several experimental studies evaluating revascularization of ischemic areas have supported this notion (Takahashi et al., 1999; Valgimigli et al., 2005; Capoccia et al., 2006; Jiao et al., 2006; Nishimura et al., 2012).

Mechanisms of Vasculogenesis by Stem/Progenitor Cells. Generally accepted mechanisms of vascular repair by progenitor cells include homing to areas needing vascular repair and extravasation in the tissues of injury, where they proliferate and stimulate the new vessel formation. However, the evidence for the trans-differentiation of cells into endothelium or integration of cells into the vessel wall is rather inadequate. This, in fact, led to the alternative hypothesis of the mechanism involving paracrine effects of the progenitor cells (Majka et al., 2001; Urbich et al., 2005). Pivotal studies by Ziebert et al. (2008) showed that sustained presence of cells in the circulation after ischemic insult is required for complete recovery of blood flow and revascularization of the injured tissue (Ziebart et al., 2008). However, depletion of cells during recovery by genetic modification of cells for an inducible thymidine kinase activity resulted in suppression of revascularization, thus strongly supporting paracrine functions as primary mechanism of vascular repair. This is further corroborated by several other studies (Burchfield and Dimmeler, 2008; Gnecchi et al., 2008; Barcelos et al., 2009). Consistent with this hypothesis, progenitor cells derived from the pathologic environment showed paracrine dysfunction in in vivo and in vitro studies (Awad et al., 2005; Schatteman et al., 2010; Jarajapu et al., 2014; Singh et al., 2014).

Clinical Significance of Circulating Vasculogenic Progenitor Cells. Several lines of evidence support the prognostic significance of vascular progenitor cells and the therapeutic potential. The number of circulating CD34 ${ }^{+}$cells was reported to be an independent risk biomarker of cardiovascular events and correlated with adverse outcomes (Hill et al., 2003; Schmidt-Lucke et al., 2005). Fadini et al. (2006) provided strong evidence for this concept in patients with metabolic syndrome or diabetic vasculopathy (Fadini et al., 2006). In patients with heart failure or acute coronary artery syndrome, a lower number of circulating progenitor cells independently predicts life-threatening outcomes (Samman Tahhan et al., 2018). High risk for cardiovascular disease in African American individuals is due to lower levels of vascular progenitor cells (Samman Tahhan et al., 2018). Given the fact that healthy microvasculature determines perfusion of brain required for cognitive functions, a lower number of progenitor cells are associated with greater cognitive decline compared with the individuals who have a higher number of cells in the circulation (Hajjar et al., 2016). Experimental studies have reported several functional deficiencies, such as migration, proliferation, vascularization of Matrigel plugs, integration into the vascular wall, or improving blood flow to ischemic areas, which signify impaired regenerative capacity of circulating HSPCs derived from individuals who are at high risk for cardiovascular diseases (Jarajapu and Grant, 2010).

Based on the accumulated literature, it is now very well accepted that the circulating vascular progenitor cells represent the regenerative capacity of an individual and have immense prognostic value, as the numbers negatively correlate with risk factors for cardiovascular disease. Lower numbers are markers of high risk and predict acute cardiovascular events. The number of progenitor cells increases by mobilization from bone marrow after an acute cardiovascular event, such as myocardial ischemia or stroke. Impaired mobilization or reparative functions of progenitor cells would result in a worse outcome.

\section{Renin-Angiotensin System}

Angiotensin II [Ang II or Ang-(1-8)] is the most prominent peptide of the classic RAS. Ang II is derived from Ang I by the enzyme ACE and largely produces cardiovascular detrimental effects by acting on the angiotensin II type 1 receptor (AT1R) (Nakashima et al., 2006). Vasoconstriction, oxidative stress, mitochondrial dysfunction, inflammation, and fibrosis are some of the known mechanisms underlying the cardiovascular pathology induced by Ang II/AT1R interaction. Therapeutic agents that oppose the ACE/Ang II/AT1R pathway are successful in the treatment of cardiopulmonary diseases. With the advent of genomic and proteomic approaches and availability of sensitive experimental approaches to integrative physiology, new members of RAS, peptide fragments, peptidases, and receptors, have been identified, and biologic functions of RAS have been expanded (Fig. 2).

The alternative ACE, ACE2, was discovered by two independent groups in 2000 (Donoghue et al., 2000; Tipnis et al., 2000). ACE2 converts Ang I to Ang-(1-9), which is a substrate for ACE, resulting in Ang-(1-7) formation. ACE2 produces Ang-(1-7) from Ang II, which has catalytic efficiency much higher than the pathway involving Ang-(1-9) and ACE (Vickers et al., 2002; Rice et al., 2004). Furthermore, ACE can convert/degrade Ang-(1-7) to Ang-(1-5), which is in agreement with the findings that Ang-(1-7) levels are increased in individuals on treatment with ACE inhibitors (ACEIs) (Chappell et al., 1998). Ang-(1-7) was thought to be acting as a physiologic counter-regulatory peptide for the actions of Ang II. By acting through MasR, Ang-(1-7) promotes vasodilation and antihypertensive, antifibrotic, antithrombotic, and antihypertrophic effects in several in vitro and in vivo experimental studies, thus making the protective pathway of RAS a potential therapeutic target for cardiovascular diseases (Santos et al., 2018). Either ACE2 or Ang-(1-7) or stable analogs of Ang-(1-7) are now being evaluated for the therapeutic potential in individuals with cardiopulmonary and ischemic vascular disorders.

\section{ACE/Ang II/AT1R Axis in Vasculogenic Progenitor Cells}

In recent years, compelling evidence has been shown for the expression and function of RAS members in both murine and human HSPCs (Strawn et al., 2004; Rodgers and Dizerega, 2013; Singh et al., 2015). Ang II has hematopoietic functions, mainly erythropoiesis and myelopoiesis, that were demonstrated by using angiotensin receptor blockers in vitro or in the mouse model of genetic ACE deficiency (Chisi et al., 1999; Cole et al., 2000; Rodgers et al., 2000). ACE is required for normal hematopoiesis, and ACEIs increase the risk for anemia (Hubert et al., 2006). Initial studies that were focused on vascular repair have demonstrated that Ang II potentiates angiogenic functions of progenitor cells. This beneficial effect was largely attributed to upregulation of VEGF and its receptor, VEGFR2. Increased vascular permeability by Ang II and VEGF would potentiate the transmigration of progenitor cells to the injured areas, which in turn participates in 


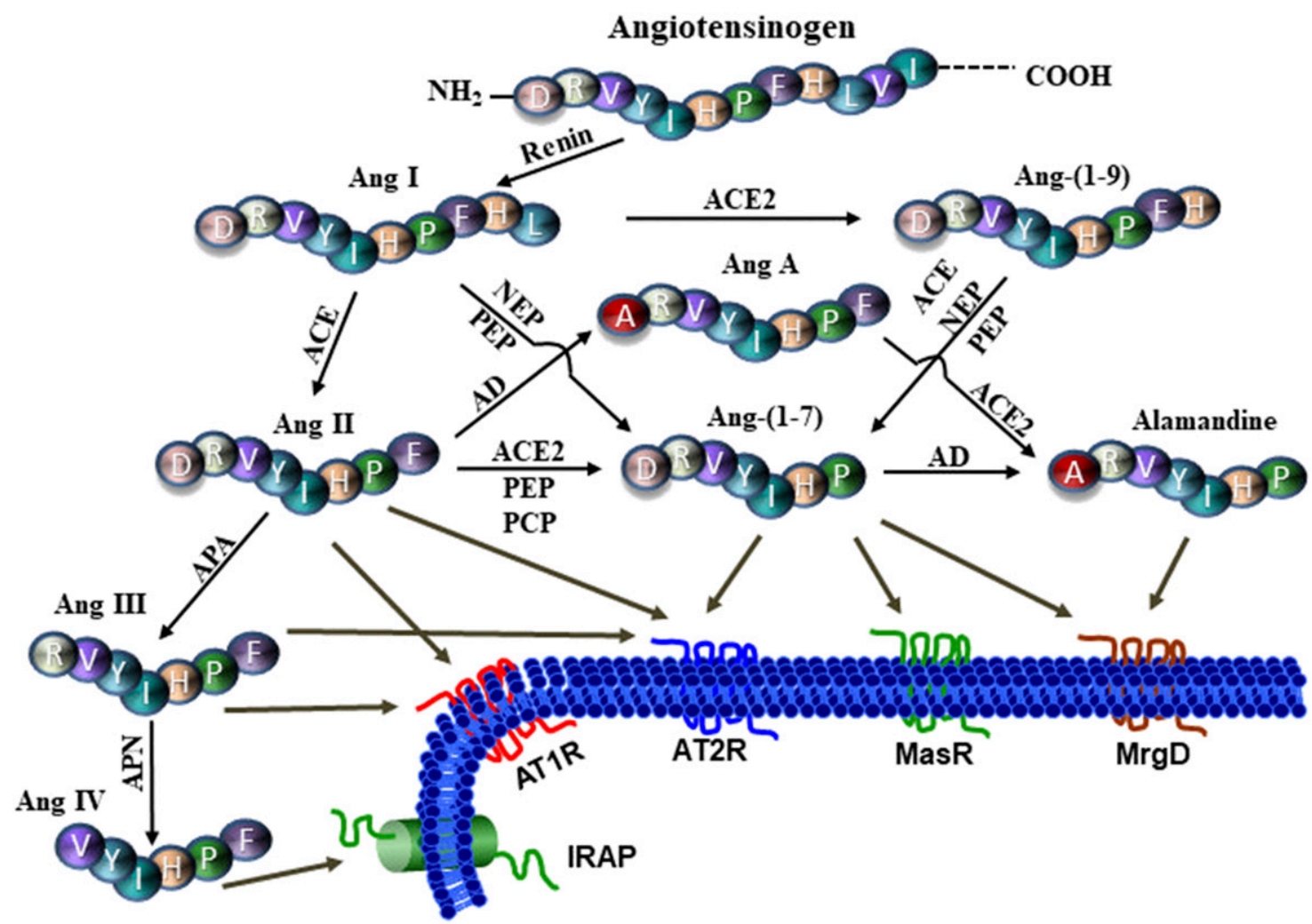

Fig. 2. Synthesis and metabolism of angiotensin peptides. Renin secreted from juxtaglomerular cells in the kidney cleaves angiotensinogen in the circulation to angiotensin-(1-10) (Ang I), which is further processed to biologically active peptides, Ang-(1-8) (Ang II) by ACE, Ang-(1-9) by ACE2, and Ang(1-7) by endopeptidases such as neprilysin (NEP) and prolylendopeptidase (PEP). Ang II is converted by ACE2 or prolylcarboxy peptidase (PCP) to generate Ang-(1-7). Ang II recognizes receptors angiotensin types 1 and 2 receptors (AT1R and AT2R, respectively), whereas Ang-(1-7) interacts with MasR, AT2R, and Mas-related G-protein-coupled receptor member D (MrgD) (Santos et al., 2003; Castro et al., 2005; Tetzner et al., 2016). Ang-(1-9) is known to activate AT2R to produce cardiovascular protective effects (not indicated by arrows) (Ocaranza and Jalil, 2012; Ocaranza et al., 2014). Angiotensin II can be further processed by aminopeptidase A (APA) to form Ang-(2-8), also known as Ang III, which has affinity for both AT1R and AT2R. (Bosnyak et al., 2011) Ang III can be cleaved by alanyl aminopeptidase N (APN) to generate Ang-(3-8), also known as Ang IV, which binds to insulinregulated membrane aminopeptidase (IRAP), also known as AT4R. (Park et al., 2015) Alternatively, angiotensin II can be processed by aspartate decarboxylase (AD) to produce Ala1-Ang-(1-8), also known as Ang A, which can be converted to Ala1-Ang-(1-7), also known as alamandine, by ACE2. Ang(1-7) can also be metabolized to alamandine by AD. Alamandine activates MrgD and elicits cardiovascular protective effects. (Lautner et al., 2013)

the process of vascular repair (Imanishi et al., 2004). In agreement with this, a study by Yin et al. (2008) has shown that vascular repair-relevant functions, such as nitric oxide (NO) generation, protection from apoptosis, and adhesion, were stimulated by Ang II. However, extensive evidence supports that overactivity of the ACE/Ang II/AT1R axis impairs cardiovascular repair and postnatal vasculogenesis at least in part by attenuating the reparative functions of progenitor cells. Activation of AT1R by hypertensive concentrations of Ang II reduced the number of circulating progenitor cells in mice and attenuated the vascular repair-relevant functions of progenitor cells, which leads to endothelial damage and impaired vascular regeneration (Endtmann et al., 2011). Activation of AT1R stimulates NADPH oxidase-dependent reactive oxygen species (ROS) generation, which in turn activates ASK-1 (poptosis signal-regulating kinase 1) and DNA damage, leading to apoptosis and senescence of progenitor cells (Imanishi et al., 2005; Endtmann et al., 2011). Hypertensive levels of Ang II induce myeloid-biased hematopoiesis in the bone marrow, resulting in the accumulation of proinflammatory monocytes (Jun et al., 2012; Kim et al., 2016), which in turn impairs angiogenesis and vascular repair (Libby, 2006; Mirza and Koh, 2011). In support of these findings, studies with ACEIs or angiotensin receptor blockers showed stimulation of regenerative functions of HSPCs and postnatal vasculogenesis in experimental models of cardiovascular disease (Kobayashi et al., 2006; Wang et al., 2006; You et al., 2008a,b; Yu et al., 2008; Müller et al., 2009).

Consistent with the experimental findings described above, clinical studies have proven that antagonism of the ACE/Ang II/AT1R axis stimulates regenerative capacity in patients with cardiovascular disease. Either telmisartan, an AT1R antagonist, or ramipril, an ACEI, increased the number of circulating HSPCs in individuals with coronary artery disease, thus enhancing the regenerative capacity that is known to be diminished in patients with cardiovascular pathologies (Porto et al., 2009; Endtmann et al., 2011; Gołąb-Janowska et al., 2018). Ramipril stimulated the vascular repair-relevant functions of HSPCs, such as proliferation, migration, adhesion, and capillary tube formation (Min et al., 2004). Along similar lines, an elegant study in patients with acute coronary syndrome demonstrated that ACEI prevented vascular endothelium from apoptosis and stimulated re-endothelialization (Cangiano et al., 2011). Although these studies collectively support detrimental effects of the ACE/Ang II/AT1R axis on the reparative functions of HSPCs, the role of Ang-(1-7) in the 
protective effects of ACEIs cannot be ruled out (Chappell et al., 1998). However, evidence for nonenzymatic or substrateindependent effects of ACE in the mobilization of HSPCs is noteworthy. Kohlstedt et al. (2018) have demonstrated that ACE negatively regulates G-CSF receptor signaling in osteoblasts and attenuates G-CSF-induced mobilization of HSPCs. ACEI or transgenic mice expressing nonphosphorylatable ACE mutant potentiate the effect of G-CSF on proliferation or mobilization of HSPCs (Lin et al., 2011; Kohlstedt et al., 2018).

Activation of AT2R is known to oppose AT1R-dependent cellular actions of Ang II. Although not well studied in the context of reparative functions by stem/progenitor cells, evidence has been provided for a potentiating role of this receptor in vasculogenic properties of progenitor cells. AT2R is expressed in bone marrow as well as cardiac progenitor cells (Ludwig et al., 2012). CD117 ${ }^{+} \mathrm{AT} 2 \mathrm{R}^{+}$mononuclear cells were shown to increase in response to ischemic injury and participate in the postischemic recovery effectively by potentiating angiogenesis independent of AT2R activation in the cardiac myocytes (Altarche-Xifró et al., 2009). Future investigations are needed to shed more light into the role of AT2R in vasoreparative functions of human HSPCs.

\section{ACE2/Ang-(1-7)/MasR Axis in Vasculogenic Progenitor Cells}

Ang-(1-7) was initially known for its potent hematopoietic functions in mouse models and human cells, and these observations were explored for the therapeutic potential in patients with cancer for stimulating hematopoietic recovery after chemoradiation therapy (Rodgers et al., 2002, 2006). Later studies have focused on the importance of this pathway in the cells that are relevant for vascular regeneration, and evidence has been accumulating in support of this novel concept. Activation of this pathway is evidently an efficient approach for stimulating proliferation of bone marrow-resident HSPCs, mobilization, and paracrine angiogenic effects, which collectively enhance revascularization of ischemic areas and tissue healing (Fig. 3), as discussed below.

Analogous to the expression of SDF or VEGF in HSPCs by HIF $1 \alpha$ (see above) upon exposure to an ischemic environment, ACE2 and MasR are hypoxia-regulated, but ACE and AT1R are not (Joshi et al., 2019). Luciferase reporter assays confirmed increased ACE2 and MasR transcription by hypoxia that was inhibited by coexpression of specific microRNAs in human HSPCs. Increased ACE2 enzyme activity was observed in both cell lysates and cell supernatants. The latter is via shedding of ACE2 ectodomain by A disintegrin and metallopeptidase domain-17, which is also upregulated by hypoxia (Hurtado et al., 2001; Joshi et al., 2019). It is interesting to note that SDF or VEGF could induce the expression of ACE2 or MasR independent of hypoxic environment. These in vitro findings are further supported by in vivo studies. In mice undergoing ischemic injury, circulating HSPCs showed increased expression of ACE2 and MasR but not ACE or AT1R compared with the circulating cells derived from nonischemic mice (Joshi et al., 2019). Taken together, these findings imply that the upregulation of ACE2 and MasR in progenitor cells that are recruited to the areas of ischemia would enhance the generation of Ang-(1-7), which, in turn, via MasR-dependent autocrine and paracrine effects on peri-ischemic endothelium,

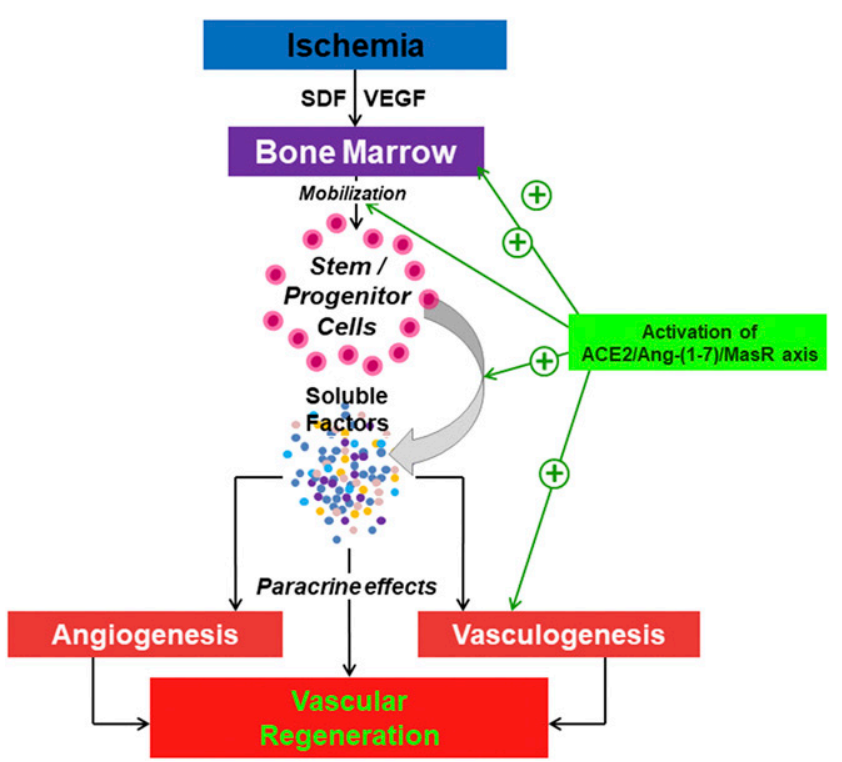

Fig. 3. Schematic of protective functions of the ACE2/Ang-(1-7)/MasR pathway in the vasoreparative functions of hematopoietic stem/progenitor cells. ACE2 and MasR are expressed in hematopoietic stem/progenitor cells and vascular endothelium. Activation of either ACE2 to generate Ang-(1-7), or MasR by exogenous Ang-(1-7), stimulates mobilization of HSPCs and angiogenic properties of secretome derived from HSPCs. In the microvascular endothelium, activation of MasR by Ang-(1-7) stimulates angiogenesis (not indicated by arrows) (Hoffmann et al., 2017). Both angiogenic and vasculogenic processes contribute to the vasoreparative functions of Ang-(1-7) (see text for details).

would further stimulate vascular regeneration and rapid recovery of organ function.

Activation of ACE2 or MasR has been shown to promote vasoreparative functions in vascular progenitor cells or to reverse reparative dysfunction in the cells derived from a pathologic environment. Activation of MasR in CD34 ${ }^{+}$cells obtained from healthy individuals has promoted vascular repair-relevant functions such as migration, proliferation, and NO generation in basal or in response to SDF or VEGF (Jarajapu et al., 2013; Singh et al., 2015). Importantly, the dysfunctional cells derived from individuals with diabetes, pulmonary hypertension, or heart failure were responsive to Ang-(1-7) and showed responses that are vascular repair-relevant (Jarajapu et al., 2013; Shenoy et al., 2013; Cole-Jeffrey et al., 2018). Lentiviral overexpression of Ang-(1-7) transgene restored migratory response of cells to SDF in vitro or migration to the areas of ischemic injury and integration into the blood vessel wall in vivo (Jarajapu et al., 2013). Along similar lines, lentiviral expression of ACE2 restored reparative functions in the dysfunctional diabetic $\mathrm{CD} 4^{+}$cells in a mouse model of critical limb ischemia (Jarajapu et al., 2017). It is worth noting that in a unique group of diabetic individuals who are resistant to the development of microvascular complications, despite having severe diabetes for a long time, expression of ACE2 was higher compared with that observed in cells derived from diabetic patients with microvascular complications (Jarajapu et al., 2013).

In vivo treatment of diabetic mice with Ang-(1-7) reversed paracrine dysfunction as assessed by using preconditioned media derived from bone marrow progenitor cells. Diabetes resulted in paracrine dysfunction of cells characterized by the inability of preconditioned medium to support migration and 
proliferation of progenitor cells, and switching the paracrine profile from proangiogenic, proliferative, and anti-inflammatory to detrimental proinflammatory and antiangiogenic and antiproliferative functions (Schatteman et al., 2010; Jarajapu et al., 2014). These dysfunctions are reversed by Ang-(1-7) treatment in a mouse model of diabetes (Singh et al., 2014). Mobilization of vascular progenitor cells is dysfunctional in conditions such as diabetes or obesity either in physiologic conditions or in response to ischemic insult (Fadini and Avogaro 2013). Ang-(17) treatment stimulated mobilization of progenitors in healthy mice that were undergoing myocardial ischemia (Wang et al., 2010). In mouse models of either type 1 or type 2 diabetes, Ang-(1-7) treatment reversed impaired mobilization in basal as well as in response to ischemic injury (Vasam et al., 2017).

Role of NO in Vasculogenic Functions of Ang-(1-7). NO has an important role in the maintenance and mobilization of progenitor cells from bone marrow (Aicher et al., 2004). NO at least in part mediates protective functions of Ang-(1-7) in the progenitor cells. In agreement with initial studies inferring MasR-dependent activation of eNOS in endothelial cells (Wiemer et al., 2002; Sampaio et al., 2007), the phosphoinositide 3-kinase/protein kinase B pathway has been shown to be involved in MasR-dependent NO release by Ang-(1-7) in human and murine HSPCs (Jarajapu et al., 2013). An oxidative environment induces uncoupling of eNOS, resulting in superoxide generation, which further exacerbates oxidative stress. In conditions such as diabetes and obesity, Ang-(1-7) is able to restore $\mathrm{NO}$ levels at least in part by reducing oxidative stress. Elegant studies have shown that bone marrow oxidative stress in mouse models of diabetes was alleviated by Ang(1-7) and increased NO/cGMP (cyclic guanosine monophosphate) levels (Mordwinkin et al., 2012; Papinska et al., 2015). CD34 cells derived from diabetic individuals have shown increased ROS levels that were normalized by Ang-(1-7), which was associated with increased NO levels (Jarajapu et al., 2013).

Evidence from MasR- or ACE2-Deficient Mice. Recent evidence points to an important role of MasR in physiologic and pharmacologic mobilization via multiple molecular mechanisms. MasR deficiency decreased the number of circulating vascular progenitor cells. Importantly, mobilization of progenitors into the circulation in response to ischemic vascular injury is severely impaired, resulting in partial recovery of blood flow to the ischemic areas (Vasam et al., 2017). Mice with ACE2 deficiency were shown to develop bone marrow dysfunction characterized by skewing hematopoiesis toward myelopoiesis, which increased the susceptibility to the development of microvascular complications (Duan et al., 2018). This observation is indeed in agreement with findings from studies using Ang II (Jun et al., 2012; Kim et al., 2016), suggesting that the absence of the counter-regulatory vasoprotective axis produces detrimental effects in the bone marrow largely via ACE/Ang II/AT1R overactivity.

Novel Role of Slit Proteins in the Mobilization of Progenitor Cells by Ang-(1-7) from Bone Marrow. A novel mechanism involving Slit proteins has been shown to be activated by Ang-(1-7) in mouse bone marrow. Slit proteins were first discovered for their important role in the context of neural development and then were shown to regulate migration of nonadherent cells by acting on a unique class of receptors, receptor of roundabout (Wang et al., 2003; Geutskens et al., 2010). Real-time polymerase chain reaction studies have detected mRNA transcripts of Slit and receptor of roundabout isoforms in both stromal cells and LSK (lineage-negative, Sca1-positive and cKit-positive) cells in mice (Vasam et al., 2017). In our studies, Slit proteins did not stimulate migratory response in murine progenitor cells but increased Rho-kinase activity. In the presence of a Slit protein, migratory response to SDF is increased concentration dependently. Furthermore, we found that Slit3 is an abundant isoform in mouse bone marrow supernatant, and its secretion by stromal cells is stimulated in vitro by Ang-(1-7) that was completely blocked by MasRantagonist A779. In vivo treatment with Ang-(1-7) did not alter Slit3 levels in healthy mice, but they were increased in diabetic mice (Vasam et al., 2017). Thus, the reversal of diabetic mobilopathy by Ang-(1-7) is at least in part due to increased slit3 levels in the bone marrow.

\section{The Promise of ACE2/Ang-(1-7)/MasR Axis in Regenerative Pharmacology}

Increasing the innate regenerative capacity is a promising therapeutic approach for clinical conditions in which tissue repair or regeneration is the most desired outcome. Aging, diabetes/obesity, hypertension, and lifestyle-Western diet, smoking, and alcoholism-are all known to decrease the number of progenitor cells and attenuate the reparative functions that are hallmarks of decreased regenerative capacity. Oxidative stress and inflammation are common pathologic features of these disorders. Therefore, autologous cell therapies are not feasible in these populations of patients. Ex vivo modification of cells to produce vasoprotective molecules that would not only restore reparative functions but also modify the pathologic milieu, would be effective in accomplishing the revascularization process. Overexpression of either VEGF or eNOS in cells would not modify the oxidative or inflammatory environment of the recipient and, instead, may cause aberrant neovascularization or overproduction of reactive oxygen species (Ozawa et al., 2004; Jarajapu et al., 2011; Mujagic et al., 2013). Overexpression of ACE2 or Ang-(1-7) by gene transfer approach with the advantage of using efficient viral vectors will have multiple benefits that would collectively stimulate vascular repair processes (Fig. 1): 1) as the cells are destined to areas of ischemia, the vasoprotective molecules will be targetdelivered; 2) increased ACE2 levels will decrease Ang II concentrations in the peri-ischemic areas and minimize or abolish the detrimental effects and simultaneously increase Ang-(1-7) generation; 3) autocrine effects of Ang-(1-7) reverse paracrine dysfunction in the progenitor cells; 4) exposure to hypoxia stimulates expression of ACE2 and MasR and increases shedding of ACE2; and 5) modified pathologic milieu, decreased oxidative stress, and attenuated proinflammatory conditions create a more favorable environment for revascularization. The proof of concept for this approach has been shown previously by using lentiviral gene transfer approaches in experimental models of cardiovascular diseases. CD $34^{+}$cells that are derived from diabetic individuals are dysfunctional, and this was reversed by lentiviral expression of Ang-(1-7) transgene; the modified cells have regained vascular repair-relevant functions in vitro and migrated to areas of ischemia in a mouse model of retinal ischemia and integrated into the microvasculature (Jarajapu et al., 2013). Similar findings were observed when dysfunctional diabetic 
cells were overexpressed with lentiviral ACE2 gene transfer in a mouse model of hindlimb ischemia (Jarajapu et al., 2017).

Pharmacologic targeting of ACE2 or MasR has been proven to be successful in experimental models for diabetic wound healing and cardiopulmonary disorders, and the reparative endpoints were associated with increased vascular regenerative capacity (Mordwinkin et al., 2012; Shenoy et al., 2013; Singh et al., 2014; Papinska et al., 2015; Vasam et al., 2017). Despite the shorter biologic half-life, Ang-(1-7) administration has been shown to be effective even in nanomolar doses in a wide range of experimental models. More stable analogs of Ang-(1-7), such as Norleucine ${ }^{3}$-Ang-(1-7)-Ang-(1-7) or glycosylated Ang-(1-7), would be better alternatives for clinical use (Rodgers et al., 2005; Hay et al., 2019). Small molecule activators of ACE2, diminazene aceturate and a xanthenone derivative, have been reported for their beneficial effects in rodent models of cardiopulmonary diseases (Ferreira et al., 2009, 2011; Fraga-Silva et al., 2013; Qi et al., 2013). Diminazene aceturate was shown to increase the circulating progenitor cells in a rodent model of pulmonary hypertension and stimulated vascular repair-relevant functions in $\mathrm{CD}_{3} 4^{+}$ HSPCs derived from healthy individuals or individuals with pulmonary hypertension (Shenoy et al., 2013; Singh et al., 2015). However, further systematic investigations are warranted to explore the pharmacology of these small molecule activators.

\section{Conclusion}

In conclusion, cell-based therapies are promising therapeutic strategies for the treatment of cardiovascular complications, especially when other available options have proven to be ineffective. However, these approaches are currently not feasible when cells are derived from a pathologic environment, as is the case with autologous cell therapies. As summarized in this review, an optimal balance in the detrimental and protective axes of RAS is critical for the regenerative functions of hematopoietic stem/progenitor cells. Functional imbalance with a hyperactive ACE or AT1R attenuates the reparative functions, which in turn leads to the development of cardiovascular pathologies. Compelling evidence has now been shown in support of the activation of ACE2/Ang-(1-7)/MasR pathway by molecular or pharmacologic maneuvers as a novel therapeutic approach for reversing dysfunctions in progenitor cells, thereby enhancing revascularization outcomes.

\section{Authorship Contributions}

Wrote or contributed to the writing of manuscript: Jarajapu.

\section{References}

Aicher A, Heeschen C, and Dimmeler S (2004) The role of NOS3 in stem cell mobilization. Trends Mol Med 10:421-425.

Altarche-Xifró W, Curato C, Kaschina E, Grzesiak A, Slavic S, Dong J, Kappert K, Steckelings M, Imboden H, Unger T, et al. (2009) Cardiac c-kit+AT2+ cell population is increased in response to ischemic injury and supports cardiomyocyte performance. Stem Cells 27:2488-2497.

Asahara T, Masuda H, Takahashi T, Kalka C, Pastore C, Silver M, Kearne M, Magner M, and Isner JM (1999) Bone marrow origin of endothelial progenitor cells responsible for postnatal vasculogenesis in physiological and pathological neovascularization. Circ Res 85:221-228.

Asahara T, Murohara T, Sullivan A, Silver M, van der Zee R, Li T, Witzenbichler B, Schatteman G, and Isner JM (1997) Isolation of putative progenitor endothelial cells for angiogenesis. Science 275:964-967.

Awad O, Dedkov EI, Jiao C, Bloomer S, Tomanek RJ, and Schatteman GC (2006) Differential Healing Activities of CD34 ${ }^{+}$and CD14 ${ }^{+}$Endothelial Cell Progenitors. Arterioscler Thromb Vasc Biol 26:758-764.
Awad O, Jiao C, Ma N, Dunnwald M, and Schatteman GC (2005) Obese diabetic mouse environment differentially affects primitive and monocytic endothelial cell progenitors. Stem Cells 23:575-583.

Ballard VL and Edelberg JM (2007) Stem cells and the regeneration of the aging cardiovascular system. Circ Res 100:1116-1127.

Barcelos LS, Duplaa C, Kränkel N, Graiani G, Invernici G, Katare R, Siragusa M, Meloni M, Campesi I, Monica M, et al. (2009) Human CD133+ progenitor cells promote the healing of diabetic ischemic ulcers by paracrine stimulation of angiogenesis and activation of Wnt signaling. Circ Res 104:1095-1102.

Bosnyak S, Jones ES, Christopoulos A, Aguilar MI, Thomas WG, and Widdop RE (2011) Relative affinity of angiotensin peptides and novel ligands at AT1 and AT2 receptors. Clin Sci (Lond) 121:297-303.

Burchfield JS and Dimmeler S (2008) Role of paracrine factors in stem and progenitor cell mediated cardiac repair and tissue fibrosis. Fibrogenesis Tissue Repair 1:4.

Burns JM, Summers BC, Wang Y, Melikian A, Berahovich R, Miao Z, Penfold ME, Sunshine MJ, Littman DR, Kuo CJ, et al. (2006) A novel chemokine receptor for SDF-1 and I-TAC involved in cell survival, cell adhesion, and tumor development. $J$ Exp Med 203:2201-2213.

Cangiano E, Marchesini J, Campo G, Francolini G, Fortini C, Carrà G, Miccoli M, Ceconi C, Tavazzi L, and Ferrari R (2011) ACE inhibition modulates endothelial apoptosis and renewal via endothelial progenitor cells in patients with acute coronary syndromes [published correction appears in Am J Cardiovasc Drugs (2012) 12 : 126]. Am J Cardiovasc Drugs 11:189-198

Capoccia BJ, Shepherd RM, and Link DC (2006) G-CSF and AMD3100 mobilize monocytes into the blood that stimulate angiogenesis in vivo through a paracrine mechanism. Blood 108:2438-2445.

Casanova-Acebes M, Pitaval C, Weiss LA, Nombela-Arrieta C, Chevre R, A-gonzalez N, Kunisaki Y, Zhang D, van Rooijen N, Silberstein LE, et al. (2013) Rhythmic modulation of the hematopoietic niche through neutrophil clearance. Cell 153:1025-1035.

Castro CH, Santos RA, Ferreira AJ, Bader M, Alenina N, and Almeida AP (2005) Evidence for a functional interaction of the angiotensin-(1-7) receptor Mas with AT1 and AT2 receptors in the mouse heart. Hypertension 46:937-942.

Chappell MC, Pirro NT, Sykes A, and Ferrario CM (1998) Metabolism of angiotensin(1-7) by angiotensin-converting enzyme. Hypertension 31:362-367.

Chisi JE, Wdzieczak-Bakala J, Thierry J, Briscoe CV, and Riches AC (1999) Captopril inhibits the proliferation of hematopoietic stem and progenitor cells in murine longterm bone marrow cultures. Stem Cells 17:339-344.

Civin CI, Strauss LC, Brovall C, Fackler MJ, Schwartz JF, and Shaper JH (1984) Antigenic analysis of hematopoiesis. III. A hematopoietic progenitor cell surface antigen defined by a monoclonal antibody raised against KG-1a cells. J Immunol 133:157-165.

Cole J, Ertoy D, Lin H, Sutliff RL, Ezan E, Guyene TT, Capecchi M, Corvol P, and Bernstein KE (2000) Lack of angiotensin II-facilitated erythropoiesis causes anemia in angiotensin-converting enzyme-deficient mice. J Clin Invest 106:1391-1398.

Cole-Jeffrey CT, Pepine CJ, Katovich MJ, Grant MB, Raizada MK, and Hazra S (2018) Beneficial effects of angiotensin-(1-7) on CD34+ cells from patients with heart failure. J Cardiovasc Pharmacol 71:155-159.

De Falco E, Porcelli D, Torella AR, Straino S, Iachininoto MG, Orlandi A, Truffa S, Biglioli P, Napolitano M, Capogrossi MC, et al. (2004) SDF-1 involvement in endothelial phenotype and ischemia-induced recruitment of bone marrow progenitor cells. Blood 104:3472-3482.

Demirer T, Bensinger WI, and Buckner CD (1999) Peripheral blood stem cell mobilization for high-dose chemotherapy. J Hematother 8:103-113.

Ding L, Saunders TL, Enikolopov G, and Morrison SJ (2012) Endothelial and perivascular cells maintain haematopoietic stem cells. Nature 481:457-462.

Donoghue M, Hsieh F, Baronas E, Godbout K, Gosselin M, Stagliano N, Donovan M, Woolf B, Robison K, Jeyaseelan R, et al. (2000) A novel angiotensin-converting enzyme-related carboxypeptidase (ACE2) converts angiotensin I to angiotensin 1-9. Circ Res 87:E1-E9.

Duan Y, Beli E, Li Calzi S, Quigley JL, Miller RC, Moldovan L, Feng D, Salazar TE, Hazra S, Al-Sabah J, et al. (2018) Loss of angiotensin-converting enzyme 2 exacerbates diabetic retinopathy by promoting bone marrow dysfunction. Stem Cells $\mathbf{3 6}$ : $1430-1440$.

Endtmann C, Ebrahimian T, Czech T, Arfa O, Laufs U, Fritz M, Wassmann K, Werner N, Petoumenos V, Nickenig G, et al. (2011) Angiotensin II impairs endothelial progenitor cell number and function in vitro and in vivo: implications for vascular regeneration. Hypertension 58:394-403.

Fadini GP and Avogaro A (2013) Diabetes impairs mobilization of stem cells for the treatment of cardiovascular disease: a meta-regression analysis. Int J Cardiol 168: 892-897.

Fadini GP, Losordo D, and Dimmeler S (2012) Critical reevaluation of endothelial progenitor cell phenotypes for therapeutic and diagnostic use. Circ Res 110:624-637.

Fadini GP, Sartore S, Albiero M, Baesso I, Murphy E, Menegolo M, Grego F, Vigili de Kreutzenberg S, Tiengo A, Agostini C, et al. (2006) Number and function of endothelial progenitor cells as a marker of severity for diabetic vasculopathy. Arterioscler Thromb Vasc Biol 26:2140-2146.

Fernandez Pujol B, Lucibello FC, Gehling UM, Lindemann K, Weidner N, Zuzarte ML, Adamkiewicz J, Elsasser HP, Muller R, and Havemann K (2000) Endothelial-like cells derived from human CD14 positive monocytes. Differentiation 65:287-300.

Ferreira AJ, Shenoy V, Qi Y, Fraga-Silva RA, Santos RAS, Katovich MJ, and Raizada MK (2011) Angiotensin-converting enzyme 2 activation protects against hypertension-induced cardiac fibrosis involving extracellular signal-regulated kinases. Exp Physiol 96:287-294.

Ferreira AJ, Shenoy V, Yamazato Y, Sriramula S, Francis J, Yuan L, Castellano RK, Ostrov DA, Oh SP, Katovich MJ, et al. (2009) Evidence for angiotensin-converting enzyme 2 as a therapeutic target for the prevention of pulmonary hypertension. Am $J$ Respir Crit Care Med 179:1048-1054.

Forsythe JA, Jiang BH, Iyer NV, Agani F, Leung SW, Koos RD, and Semenza GL (1996) Activation of vascular endothelial growth factor gene transcription by hypoxia-inducible factor 1. Mol Cell Biol 16:4604-4613. 
Fraga-Silva RA, Ferreira AJ, and Dos Santos RAS (2013) Opportunities for targeting the angiotensin-converting enzyme 2/angiotensin-(1-7)/mas receptor pathway in hypertension. Curr Hypertens Rep 15:31-38.

Gehling UM, Ergun S, Schumacher U, Wagener C, Pantel K, Otte M, Schuch G, Schafhausen P, Mende T, Kilic N, et al. (2000) In vitro differentiation of endothelial cells from AC133-positive progenitor cells. Blood 95:3106-3112.

Geutskens SB, Hordijk PL, and van Hennik PB (2010) The chemorepellent Slit3 promotes monocyte migration. J Immunol 185:7691-7698.

Gill M, Dias S, Hattori K, Rivera ML, Hicklin D, Witte L, Girardi L, Yurt R, Himel H, and Rafii S (2001) Vascular trauma induces rapid but transient mobilization of VEGFR2(+)AC133(+) endothelial precursor cells. Circ Res 88:167-174.

Gnecchi M, Zhang Z, Ni A, and Dzau VJ (2008) Paracrine mechanisms in adult stem cell signaling and therapy. Circ Res 103:1204-1219.

Gołąb-Janowska M, Paczkowska E, Machaliński B, Kotlęga D, Meller A, Safranow K, Maj M, and Nowacki P (2018) Effects of angiotensin-converting enzyme inhibition on circulating endothelial progenitor cells in patients with acute ischemic stroke. Stem Cells Int 2018:2827580.

Grunewald M, Avraham I, Dor Y, Bachar-Lustig E, Itin A, Jung S, Chimenti S, Landsman L, Abramovitch R, and Keshet E (2006) VEGF-induced adult neovascularization: recruitment, retention, and role of accessory cells [published correction appears in Cell (2006) 126:811]. Cell 124:175-189.

Hajjar I, Goldstein FC, Waller EK, Moss LD, and Quyyumi A (2016) Circulating progenitor cells is linked to cognitive decline in healthy adults. Am J Med Sci $\mathbf{3 5 1}$ $147-152$.

Harraz M, Jiao C, Hanlon HD, Hartley RS, and Schatteman GC (2001) CD34- BloodDerived Human Endothelial Cell Progenitors. Stem Cells 19:304-312.

Hattori K, Dias S, Heissig B, Hackett NR, Lyden D, Tateno M, Hicklin DJ, Zhu Z, Witte L, Crystal RG, et al. (2001) Vascular endothelial growth factor and angiopoietin-1 stimulate postnatal hematopoiesis by recruitment of vasculogenic and hematopoietic stem cells. J Exp Med 193:1005-1014.

Hay M, Polt R, Heien ML, Vanderah TW, Largen-Milnes TM, Rodgers KE, Falk T, Bartlett MJ, Doyle K, and Konhilas J (2019) A novel angiotensin-(1-7) glycosylated mas receptor agonist for treating vascular cognitive impairment and inflammationrelated memory dysfunction. J Pharmacol Exp Ther 369:9-25.

Henry TD, Losordo DW, Traverse JH, Schatz RA, Jolicoeur EM, Schaer GL, Clare R, Chiswell K, White CJ, Fortuin FD, et al. (2018) Autologous CD34+ cell therapy improves exercise capacity, angina frequency and reduces mortality in no-option refractory angina: a patient-level pooled analysis of randomized double-blinded trials. Eur Heart $J$ 39:2208-2216.

Hill JM, Zalos G, Halcox JPJ, Schenke WH, Waclawiw MA, Quyyumi AA, and Finkel T (2003) Circulating endothelial progenitor cells, vascular function, and cardiovascular risk. $N$ Engl J Med 348:593-600.

Hoffmann BR, Stodola TJ, Wagner JR, Didier DN, Exner EC, Lombard JH and Greene AS (2017) Mechanisms of Mas1 receptor-mediated signaling in the vascular endothelium. Arterioscler Thromb Vasc Biol 37:433-445.

Hubert C, Savary K, Gasc JM, and Corvol P (2006) The hematopoietic system: a new niche for the renin-angiotensin system. Nat Clin Pract Cardiovasc Med 3:80-85.

Hurtado O, Cárdenas A, Lizasoain I, Boscá L, Leza JC, Lorenzo P, and Moro MA (2001) Up-regulation of TNF-alpha convertase (TACE/ADAM17) after oxygenglucose deprivation in rat forebrain slices. Neuropharmacology 40:1094-1102.

Imanishi T, Hano T, and Nishio I (2004) Angiotensin II potentiates vascular endothelial growth factor-induced proliferation and network formation of endothelial progenitor cells. Hypertens Res 27:101-108.

Imanishi T, Hano T, and Nishio I (2005) Angiotensin II accelerates endothelial progenitor cell senescence through induction of oxidative stress. J Hypertens 23 97-104.

Itkin T, Gur-Cohen S, Spencer JA, Schajnovitz A, Ramasamy SK, Kusumbe AP, Ledergor G, Jung Y, Milo I, Poulos MG, et al. (2016) Distinct bone marrow blood vessels differentially regulate haematopoiesis. Nature 532:323-328.

Jarajapu YP, Joshi S, Quiroz-Olvera JC, Duran-Mendez M, Cantu-Delgado W, Gomez SC, Bartelmez SH, Raizada MK, and Garcia C (2017) Abstract 011: ACE2 gene transfer ameliorates dysfunctions in hematopoietic stem/progenitor cells of diabetic patients. Hypertension 70:A011.

Jarajapu YPR, Bhatwadekar AD, Caballero S, Hazra S, Shenoy V, Medina R, Kent D, Stitt AW, Thut C, Finney EM, et al. (2013) Activation of the ACE2/angiotensin-(1-7)/ Mas receptor axis enhances the reparative function of dysfunctional diabetic endothelial progenitors. Diabetes 62:1258-1269.

Jarajapu YPR, Caballero S, Verma A, Nakagawa T, Lo MC, Li Q, and Grant MB (2011) Blockade of NADPH oxidase restores vasoreparative function in diabetic CD34+ cells. Invest Ophthalmol Vis Sci 52:5093-5104.

Jarajapu YPR and Grant MB (2010) The promise of cell-based therapies for diabetic complications: challenges and solutions. Circ Res 106:854-869.

Jarajapu YPR, Hazra S, Segal M, Li Calzi S, Jadhao C, Qian K, Mitter SK, Raizada MK, Boulton ME, and Grant MB (2014) Vasoreparative dysfunction of CD34+ cells in diabetic individuals involves hypoxic desensitization and impaired autocrine/ paracrine mechanisms [published correction appears in PLoS One 9:e103913]. PLoS One 9:e93965.

Jiao C, Fricker S, and Schatteman GC (2006) The chemokine (C-X-C motif) receptor 4 inhibitor AMD3100 accelerates blood flow restoration in diabetic mice. Diabetologia 49:2786-2789.

Jin DK, Shido K, Kopp HG, Petit I, Shmelkov SV, Young LM, Hooper AT, Amano H, Avecilla ST, Heissig B, et al. (2006) Cytokine-mediated deployment of SDF-1 induces revascularization through recruitment of CXCR4+ hemangiocytes. Nat Med 12:557-567.

Joshi S, Wollenzien H, Leclerc E, and Jarajapu YP (2019) Hypoxic regulation of angiotensin-converting enzyme 2 and Mas receptor in human CD34 ${ }^{+}$cells. $J$ Cell Physiol 234:20420-20431.

Jun JY, Zubcevic J, Qi Y, Afzal A, Carvajal JM, Thinschmidt JS, Grant MB, Mocco J, and Raizada MK (2012) Brain-mediated dysregulation of the bone marrow activity in angiotensin II-induced hypertension. Hypertension 60:1316-1323.
Kim S, Zingler M, Harrison JK, Scott EW, Cogle CR, Luo D, and Raizada MK (2016) Angiotensin II regulation of proliferation, differentiation, and engraftment of hematopoietic stem cells. Hypertension 67:574-584.

Kobayashi K, Imanishi T, and Akasaka T (2006) Endothelial progenitor cell differentiation and senescence in an angiotensin II-infusion rat model. Hypertens Res 29 : $449-455$.

Kohlstedt K, Trouvain C, Frömel T, Mudersbach T, Henschler R, and Fleming I (2018) Role of the angiotensin-converting enzyme in the G-CSF-induced mobilization of progenitor cells. Basic Res Cardiol 113:18.

Kunisaki Y, Bruns I, Scheiermann C, Ahmed J, Pinho S, Zhang D, Mizoguchi T, Wei Q, Lucas D, Ito K, et al. (2013) Arteriolar niches maintain haematopoietic stem cell quiescence. Nature 502:637-643.

Lautner RQ, Villela DC, Fraga-Silva RA, Silva N, Verano-Braga T, Costa-Fraga F, Jankowski J, Jankowski V, Sousa F, Alzamora A, et al. (2013) Discovery and characterization of alamandine: a novel component of the renin-angiotensin system [published correction appears in Circ Res 112:e156]. Circ Res 112:1104-1111.

Libby P (2006) Inflammation and cardiovascular disease mechanisms. Am J Clin Nutr 83:456S-460S

Lin C, Datta V, Okwan-Duodu D, Chen X, Fuchs S, Alsabeh R, Billet S, Bernstein KE, and Shen XZ (2011) Angiotensin-converting enzyme is required for normal myelopoiesis. FASEB $J$ 25:1145-1155.

Loomans CJ, Han H, de Crom R, van Haperen R, de Boer HC, Leenen PJ, Drexhage HA, Rabelink TJ, van Zonneveld AJ, and Staal FJ (2006) Angiogenic murine endothelial progenitor cells are derived from a myeloid bone marrow fraction and can be identified by endothelial NO synthase expression. Arterioscler Tromb Vasc Biol 26:1760-1767.

Lucas D, Battista M, Shi PA, Isola L, and Frenette PS (2008) Mobilized hematopoietic stem cell yield depends on species-specific circadian timing. Cell Stem Cell 3: 364-366.

Ludwig M, Steinhoff G, and Li J (2012) The regenerative potential of angiotensin AT2 receptor in cardiac repair. Can J Physiol Pharmacol 90:287-293.

Majka M, Janowska-Wieczorek A, Ratajczak J, Ehrenman K, Pietrzkowski Z Kowalska MA, Gewirtz AM, Emerson SG, and Ratajczak MZ (2001) Numerous growth factors, cytokines, and chemokines are secreted by human CD34(+) cells, myeloblasts, erythroblasts, and megakaryoblasts and regulate normal hematopoiesis in an autocrine/paracrine manner. Blood 97:3075-3085

Maxwell PH, Dachs GU, Gleadle JM, Nicholls LG, Harris AL, Stratford IJ, Hankinson O, Pugh CW, and Ratcliffe PJ (1997) Hypoxia-inducible factor-1 modulates gene expression in solid tumors and influences both angiogenesis and tumor growth. Proc Natl Acad Sci USA 94:8104-8109.

Méndez-Ferrer S, Michurina TV, Ferraro F, Mazloom AR, Macarthur BD, Lira SA Scadden DT, Ma'ayan A, Enikolopov GN, and Frenette PS (2010) Mesenchymal and haematopoietic stem cells form a unique bone marrow niche. Nature 466: 829-834

Min TQ, Zhu CJ, Xiang WX, Hui ZJ, and Peng SY (2004) Improvement in endothelial progenitor cells from peripheral blood by ramipril therapy in patients with stable coronary artery disease. Cardiovasc Drugs Ther 18:203-209.

Mirza R and Koh TJ (2011) Dysregulation of monocyte/macrophage phenotype in wounds of diabetic mice. Cytokine 56:256-264.

Mordwinkin NM, Meeks CJ, Jadhav SS, Espinoza T, Roda N, diZerega GS, Louie SG, and Rodgers KE (2012) Angiotensin-(1-7) administration reduces oxidative stress in diabetic bone marrow. Endocrinology 153:2189-2197.

Mujagic E, Gianni-Barrera R, Trani M, Patel A, Gürke L, Heberer M, Wolff T, and Banfi A (2013) Induction of aberrant vascular growth, but not of normal angiogenesis, by cell-based expression of different doses of human and mouse VEGF is species-dependent. Hum Gene Ther Methods 24:28-37.

Müller P, Kazakov A, Jagoda P, Semenov A, Böhm M, and Laufs U (2009) ACE inhibition promotes upregulation of endothelial progenitor cells and neoangiogenesis in cardiac pressure overload. Cardiovasc Res 83:106-114.

Nakashima H, Suzuki H, Ohtsu H, Chao JY, Utsunomiya H, Frank GD, and Eguchi S (2006) Angiotensin II regulates vascular and endothelial dysfunction: recent topics of Angiotensin II type-1 receptor signaling in the vasculature. Curr Vasc Pharmacol 4:67-78.

Nishimura Y, Ii M, Qin G, Hamada H, Asai J, Takenaka H, Sekiguchi H, Renault M-A Jujo K, Katoh N, et al. (2012) CXCR4 antagonist AMD3100 accelerates impaired wound healing in diabetic mice. J Invest Dermatol 132:711-720.

Ocaranza MP and Jalil JE (2012) Protective role of the ACE2/Ang-(1-9) axis in cardiovascular remodeling. Int $J$ Hypertens 2012:594361.

Ocaranza MP, Moya J, Barrientos V, Alzamora R, Hevia D, Morales C, Pinto M, Escudero N, García L, Novoa U, et al. (2014) Angiotensin-(1-9) reverses experimental hypertension and cardiovascular damage by inhibition of the angiotensin converting enzyme/Ang II axis. J Hypertens 32:771-783.

Ozawa CR, Banfi A, Glazer NL, Thurston G, Springer ML, Kraft PE, McDonald DM, and Blau HM (2004) Microenvironmental VEGF concentration, not total dose, determines a threshold between normal and aberrant angiogenesis. $J$ Clin Invest 113:516-527.

Papinska AM, Mordwinkin NM, Meeks CJ, Jadhav SS, and Rodgers KE (2015) Angiotensin-(1-7) administration benefits cardiac, renal and progenitor cell function in $\mathrm{db} / \mathrm{db}$ mice. Br J Pharmacol 172:4443-4453.

Park BM, Cha SA, Han BR, and Kim SH (2015) Angiotensin IV stimulates high atrial stretch-induced ANP secretion via insulin regulated aminopeptidase. Peptides 63: 30-37.

Peichev M, Naiyer AJ, Pereira D, Zhu Z, Lane WJ, Williams M, Oz MC, Hicklin DJ, Witte L, Moore MA, et al. (2000) Expression of VEGFR-2 and AC133 by circulating human CD34 $4^{+}$cells identifies a population of functional endothelial precursors. Blood 95:952-958.

Porto I, Di Vito L, De Maria GL, Dato I, Tritarelli A, Leone AM, Niccoli G, Capogrossi MC, Biasucci LM, and Crea F (2009) Comparison of the effects of ramipril versus telmisartan on high-sensitivity C-reactive protein and endothelial progenitor cells after acute coronary syndrome. Am J Cardiol 103:1500-1505. 
Qi Y, Zhang J, Cole-Jeffrey CT, Shenoy V, Espejo A, Hanna M, Song C, Pepine CJ, Katovich MJ, and Raizada MK (2013) Diminazene aceturate enhances angiotensinconverting enzyme 2 activity and attenuates ischemia-induced cardiac pathophysiology. Hypertension 62:746-752.

Quirici N, Soligo D, Caneva L, Servida F, Bossolasco P, and Deliliers GL (2001) Differentiation and expansion of endothelial cells from human bone marrow $\mathrm{CD}_{133^{+}}$ cells. Br J Haematol 115:186-194.

Quyyumi AA, Vasquez A, Kereiakes DJ, Klapholz M, Schaer GL, Abdel-Latif A, Frohwein S, Henry TD, Schatz RA, Dib N, et al. (2017) PreSERVE-AMI: a randomized, double-blind, placebo-controlled clinical trial of intracoronary administration of autologous CD34+ cells in patients with left ventricular dysfunction post STEMI. Circ Res 120:324-331.

Raval Z and Losordo DW (2013) Cell therapy of peripheral arterial disease: from experimental findings to clinical trials. Circ Res 112:1288-1302.

Rice GI, Thomas DA, Grant PJ, Turner AJ, and Hooper NM (2004) Evaluation of angiotensin-converting enzyme (ACE), its homologue ACE2 and neprilysin in angiotensin peptide metabolism. Biochem $J$ 383:45-51.

Rodgers KE and Dizerega GS (2013) Contribution of the local RAS to hematopoietic function: a novel therapeutic target. Front Endocrinol (Lausanne) 4:157.

Rodgers KE, Ellefson DD, Espinoza T, Maulhardt H, Roda N, Maldonado S, and DiZerega GS (2005) Fragments of Nle3-angiotensin(1-7) accelerate healing in dermal models. J Pept Res 66:41-47.

Rodgers KE, Oliver J, and diZerega GS (2006) Phase I/II dose escalation study of angiotensin 1-7 [A(1-7)] administered before and after chemotherapy in patient with newly diagnosed breast cancer. Cancer Chemother Pharmacol 57:559-568.

Rodgers KE, Xiong S, and diZerega GS (2002) Accelerated recovery from irradiation injury by angiotensin peptides. Cancer Chemother Pharmacol 49:403-411.

Rodgers KE, Xiong S, Steer R, and diZerega GS (2000) Effect of angiotensin II on hematopoietic progenitor cell proliferation. Stem Cells 18:287-294.

Samman Tahhan A, Hammadah M, Raad M, Almuwaqqat Z, Alkhoder A, Sandesara PB, Mohamed-Kelli H, Hayek SS, Kim JH, O'Neal WT, et al. (2018) Progenitor cells and clinical outcomes in patients with acute coronary syndromes. Circ Res 122 $1565-1575$

Sampaio WO, Souza dos Santos RA, Faria-Silva R, da Mata Machado LT, Schiffrin EL and Touyz RM (2007) Angiotensin-(1-7) through receptor Mas mediates endothelial nitric oxide synthase activation via Akt-dependent pathways. Hypertension 49: 185-192.

Santos RA, Simoes e Silva AC, Maric C, Silva DM, Machado RP, de Buhr I, HeringerWalther S, Pinheiro SV, Lopes MT, Bader M, et al. (2003) Angiotensin-(1-7) is an endogenous ligand for the G protein-coupled receptor Mas. Proc Natl Acad Sci USA 100:8258-8263

Santos RAS, Sampaio WO, Alzamora AC, Motta-Santos D, Alenina N, Bader M, and Campagnole-Santos MJ (2018) The ACE2/angiotensin-(1-7)/MAS axis of the renin-angiotensin system: focus on angiotensin-(1-7). Physiol Rev 98:505-553.

Schatteman GC, Awad O, Nau E, Wang C, Jiao C, Tomanek RJ, and Dunnwald M (2010) Lin- cells mediate tissue repair by regulating MCP-1/CCL-2. Am J Pathol 177:2002-2010.

Schmeisser A, Garlichs CD, Zhang H, Eskafi S, Graffy C, Ludwig J, Strasser RH and Daniel WG (2001) Monocytes coexpress endothelial and macrophagocytic lineage markers and form cord-like structures in Matrigel under angiogenic conditions. Cardiovasc Res 49:671-680.

Schmidt-Lucke C, Rössig L, Fichtlscherer S, Vasa M, Britten M, Kämper U, Dimmeler S, and Zeiher AM (2005) Reduced number of circulating endothelial progenitor cells predicts future cardiovascular events: proof of concept for the clinical importance of endogenous vascular repair. Circulation 111:2981-2987.

Shenoy V, Ferreira AJ, Qi Y, Fraga-Silva RA, Díez-Freire C, Dooies A, Jun JY, Sriramula S, Mariappan N, Pourang D, et al. (2010) The angiotensin-converting enzyme 2/angiogenesis-(1-7)/Mas axis confers cardiopulmonary protection against lung fibrosis and pulmonary hypertension. Am J Respir Crit Care Med 182:1065-1072.

Shenoy V, Gjymishka A, Jarajapu YP, Qi Y, Afzal A, Rigatto K, Ferreira AJ, FragaSilva RA, Kearns P, Douglas JY, et al. (2013) Diminazene attenuates pulmonary hypertension and improves angiogenic progenitor cell functions in experimental models. Am J Respir Crit Care Med 187:648-657.

Shi Q, Rafii S, Wu MH, Wijelath ES, Yu C, Ishida A, Fujita Y, Kothari S, Mohle R, Sauvage LR, et al. (1998) Evidence for circulating bone marrow-derived endothelial cells. Blood 92:362-367.

Shweiki D, Itin A, Soffer D, and Keshet E (1992) Vascular endothelial growth factor induced by hypoxia may mediate hypoxia-initiated angiogenesis. Nature $\mathbf{3 5 9}$ $843-845$.

Singh N, Joshi S, Guo L, Baker MB, Li Y, Castellano RK, Raizada MK, and Jarajapu YPR (2015) ACE2/Ang-(1-7)/Mas axis stimulates vascular repair-relevant functions of CD34+ cells. Am J Physiol Heart Circ Physiol 309:H1697-H1707.

Singh N, Vasam G, Pawar R, and Jarajapu YPR (2014) Angiotensin-(1-7) reverses angiogenic dysfunction in corpus cavernosum by acting on the microvasculature and bone marrow-derived cells in diabetes. $J$ Sex Med 11:2153-2163.

Strawn WB, Richmond RS, Ann Tallant E, Gallagher PE, and Ferrario CM (2004) Renin-angiotensin system expression in rat bone marrow haematopoietic and stromal cells. Br J Haematol 126:120-126.

Stump MM, Jordan GL Jr, Debakey ME, and Halpert B (1963) Endothelium grown from circulating blood on isolated intravascular dacron hub. Am J Pathol 43: 361-367.
Sweeney EA, Lortat-Jacob H, Priestley GV, Nakamoto B, and Papayannopoulou T (2002) Sulfated polysaccharides increase plasma levels of SDF-1 in monkeys and mice: involvement in mobilization of stem/progenitor cells. Blood 99:44-51.

Takahashi T, Kalka C, Masuda H, Chen D, Silver M, Kearney M, Magner M, Isner JM, and Asahara T (1999) Ischemia- and cytokine-induced mobilization of bone marrowderived endothelial progenitor cells for neovascularization. Nat Med 5:434-438.

Tavian M, Coulombel L, Luton D, Clemente HS, Dieterlen-Lièvre F, and Péault B (1996) Aorta-associated CD34+ hematopoietic cells in the early human embryo. Blood 87:67-72.

Tetzner A, Gebolys K, Meinert C, Klein S, Uhlich A, Trebicka J, Villacañas Ó, and Walther T (2016) G-protein-coupled receptor MrgD is a receptor for angiotensin-(17) involving adenylyl cyclase, cAMP, and Phosphokinase A. Hypertension 68:185-194.

Timmermans F, Plum J, Yöder MC, Ingram DA, Vandekerckhove B, and Case J (2009) Endothelial progenitor cells: identity defined? J Cell Mol Med 13:87-102.

Tipnis SR, Hooper NM, Hyde R, Karran E, Christie G, and Turner AJ (2000) A human homolog of angiotensin-converting enzyme. Cloning and functional expression as a captopril-insensitive carboxypeptidase. J Biol Chem 275:33238-33243.

Urbich C, Aicher A, Heeschen C, Dernbach E, Hofmann WK, Zeiher AM, and Dimmeler S (2005) Soluble factors released by endothelial progenitor cells promote migration of endothelial cells and cardiac resident progenitor cells. $J \mathrm{Mol}$ Cell Cardiol 39:733-742.

Valgimigli M, Rigolin GM, Cittanti C, Malagutti P, Curello S, Percoco G, Bugli AM, Della Porta M, Bragotti LZ, Ansani L, et al. (2005) Use of granulocyte-colony stimulating factor during acute myocardial infarction to enhance bone marrow stem cell mobilization in humans: clinical and angiographic safety profile. Eur Heart $J \mathbf{2 6}$ 1838-1845.

Vasam G, Joshi S, Thatcher SE, Bartelmez SH, Cassis LA, and Jarajapu YPR (2017) Reversal of bone marrow mobilopathy and enhanced vascular repair by angiotensin(1-7) in diabetes. Diabetes 66:505-518.

Vickers C, Hales P, Kaushik V, Dick L, Gavin J, Tang J, Godbout K, Parsons T, Baronas E, Hsieh F, et al. (2002) Hydrolysis of biological peptides by human angiotensinconverting enzyme-related carboxypeptidase. J Biol Chem 277:14838-14843.

Wang B, Xiao Y, Ding B-B, Zhang N, Yuan Xb, Gui L, Qian K-X, Duan S, Chen Z, Rao $\mathrm{Y}$, et al. (2003) Induction of tumor angiogenesis by Slit-Robo signaling and inhibition of cancer growth by blocking Robo activity. Cancer Cell 4:19-29.

Wang CH, Verma S, Hsieh IC, Chen YJ, Kuo LT, Yang NI, Wang SY, Wu MY, Hsu CM, Cheng CW, et al. (2006) Enalapril increases ischemia-induced endothelial progenitor cell mobilization through manipulation of the CD26 system. $J$ Mol Cell Cardiol 41:34-43.

Wang GL, Jiang BH, Rue EA, and Semenza GL (1995) Hypoxia-inducible factor 1 is a basic-helix-loop-helix-PAS heterodimer regulated by cellular $\mathrm{O}_{2}$ tension. Proc Natl Acad Sci USA 92:5510-5514.

Wang Y, Qian C, Roks AJM, Westermann D, Schumacher S-M, Escher F, Schoemaker RG, Reudelhuber TL, van Gilst WH, Schultheiss H-P, et al. (2010) Circulating rather than cardiac angiotensin-(1-7) stimulates cardioprotection after myocardial infarction. Circ Heart Fail 3:286-293.

Wiemer G, Dobrucki LW, Louka FR, Malinski T, and Heitsch H (2002) AVE 0991, a nonpeptide mimic of the effects of angiotensin-(1-7) on the endothelium. Hypertension 40:847-852.

Wood HB, May G, Healy L, Enver T, and Morriss-Kay GM (1997) CD34 expression patterns during early mouse development are related to modes of blood vessel formation and reveal additional sites of hematopoiesis. Blood 90:2300-2311.

Wu MH-D, Shi Q, Wechezak AR, Clowes AW, Gordon IL, and Sauvage LR (1995) Definitive proof of endothelialization of a Dacron arterial prosthesis in a human being. J Vasc Surg 21:862-867.

Yin T, Ma X, Zhao L, Cheng K, and Wang H (2008) Angiotensin II promotes NO production, inhibits apoptosis and enhances adhesion potential of bone marrowderived endothelial progenitor cells. Cell Res 18:792-799.

Yoder MC (2013) Endothelial progenitor cell: a blood cell by many other names may serve similar functions. J Mol Med (Berl) 91:285-295.

You D, Cochain C, Loinard C, Vilar J, Mees B, Duriez M, Lévy BI, and Silvestre J-S (2008a) Combination of the angiotensin-converting enzyme inhibitor perindopril and the diuretic indapamide activate postnatal vasculogenesis in spontaneously hypertensive rats. J Pharmacol Exp Ther 325:766-773.

You D, Cochain C, Loinard C, Vilar J, Mees B, Duriez M, Lévy BI, and Silvestre J-S (2008b) Hypertension impairs postnatal vasculogenesis: role of antihypertensive agents. Hypertension 51:1537-1544.

Yu Y, Fukuda N, Yao E-H, Matsumoto T, Kobayashi N, Suzuki R, Tahira Y, Ueno T, and Matsumoto K (2008) Effects of an ARB on endothelial progenitor cell function and cardiovascular oxidation in hypertension. Am $J$ Hypertens 21:72-77.

Ziebart T, Yoon C-H, Trepels T, Wietelmann A, Braun T, Kiessling F, Stein S, Grez M, Ihling C, Muhly-Reinholz M, et al. (2008) Sustained persistence of transplanted proangiogenic cells contributes to neovascularization and cardiac function after ischemia. Circ Res 103:1327-1334.

Address correspondence to: Dr. Yagna P.R. Jarajapu, Department of Pharmaceutical Sciences, College of Health Professions, North Dakota State University, Sudro-16, Albrecht Blvd., Fargo, ND 58105. E-mail: Yagna.Jarajapu@ndsu.edu 